\title{
Oculocutaneous albinism type 3
}

INSERM

\section{Source}

INSERM. (1999). Orphanet: an online rare disease and orphan drug data base.

Oculocutaneous albinism type 3. ORPHA:79433

Type 3 oculocutaneous albinism (OCA3) is a form of oculocutaneous albinism (OCA; see this term) characterized by rufous or brown albinism and occurring mainly in the African population. 